\title{
DIGITALCOMMONS
}

@WAYNESTATE -

Wayne State University

Administrative and Organizational Studies

College of Education

1-1-2009

\section{Using the Definition as a Compass to Teach Backgrounds, Issues and Trends}

Monica W. Tracey

Wayne State University, Monicatracey@wayne.edu

\section{Recommended Citation}

Tracey, M. W. (2009). Using the Definition as a Compass to Teach Backgrounds, Issues, and Trends. TechTrends, 53(5), 41. Available at: http://digitalcommons.wayne.edu/coe_aos/8

This Article is brought to you for free and open access by the College of Education at DigitalCommons@WayneState. It has been accepted for inclusion in Administrative and Organizational Studies by an authorized administrator of DigitalCommons@WayneState. 
Educational Technology Definition 1

Using the Definition as a Compass to Teach Backgrounds, Issues and Trends

Monica W. Tracey

Wayne State University

Detroit, MI 48202

monicatracey@wayne.edu 


\begin{abstract}
The "issues and trends" graduate course at Wayne State University endeavors to prepare professionals who have a historical and philosophical grounding in addition to technical skills. In this course the definitions of educational and instructional technology that have emerged over the years are viewed as compasses, pointing to concepts and issues predominant in each historical period. AECT's current definition book, Educational technology: A definition with commentary (Januszewski \& Molenda, 2008) provides the core readings for this course. Specific issues and the class activities associated with each are discussed.
\end{abstract}

\author{
Key words: \\ definition of educational technology \\ historical foundations \\ management foundations \\ professional preparation \\ psychological foundations
}




\section{Rationale}

The first formal definition of Instructional/Educational Technology was promulgated by DAVI, the predecessor of AECT, in 1963 (Ely). Each new definition, revisited and updated over the last 55 years, continues to serve as a compass, pointing to new directions for the field. In parallel with the evolution of the field and the documented definitions, professional practice continues to change and evolve. In an effort to meet the challenges posed by ongoing changes, continual efforts are necessary to interweave research, practice and theory development and to demonstrate what works in improving learning, instruction and performance. These efforts include working with graduate students preparing for careers in educational technology, to help them attain a conceptual framework consistent with the changing perspectives of the field.

Wayne State's Issues and Trends Course

"Backgrounds, Issues and Trends in Instructional Technology" (IT 8100), is an advanced graduate course taught in Wayne State University's instructional technology program. It is based on the premise that professionals, in any field, should be equipped with more than just the skills associated with that field. This course addresses that need by helping students learn about the field's history, its current status, and the trends and issues likely to have an impact on the field. This course is an ideal venue to use the new AECT definition book (Januszewski \& Molenda, 2008) as one of the required texts since the book serves as a map of the historical evolution of educational technology.

\section{Course Organization}

The course runs throughout a 15 -week semester, and meets once a week for approximately three hours and 20 minutes each class. Course outcomes include: 
1. To explore the history of the field of instructional technology, including:

- Practice history

- Intellectual history

2. To analyze the foundations of instructional technology, including:

- Communications foundations

- Audio-visual foundations

- Systems approach foundations

- Psychological and philosophical foundations

- Management foundations

3. To describe and analyze the contributions of key leaders in the field throughout its history.

4. To explore the various positions on key issues currently confronting the field, and to formulate one's own position with respect to these issues.

5. To analyze trends in the field and determine the likely impact of such trends on future theory and practice.

Course requirements include:

1. Classroom attendance and learning

2. Take home mid-term and final exam

3. On-line discussions

4. Group project focusing on a current in-depth issue facing the field

5. Research paper examining one historical theme or influential person.

Sequence of Topics 
Class begins by exploring the very concepts of educational and instructional technology in their historical context. In preparation, students are assigned readings (see Table 1), including Chapters 1 and 10 in Januszewski and Molenda (2008). I initiate the discussion with two open-ended questions: (1) What is technology? and (2) What is the name of the field? In order to address these questions, support from the literature is essential and students are provided a plethora of reference materials posted on the class web site and hardcopy materials in the classroom.

\section{[Place Table 1 about here.]}

In an effort to answer the first question, students form sub-groups of three to four students, and share and record their thoughts with literature support. We then convene and as a class reach consensus on a definition of technology.

Critical analysis of the definitions of instructional/educational technology is a significant factor when looking at the overall evolution of our field. To address the second question the class is divided into two groups and a debate commences with one team defending the term educational technology while the other states its position for instructional technology. We continue with a discussion of how the definition establishes a field's boundaries, identifies the rightful problems, and adds to the knowledge base in the field, and then review a brief history of the definitions while each is posted (shown in Table 2) on the classroom wall. The posted wall size timeline identifying definitions in 10 year increments from 1900 through 2010 provides the backdrop for the era of that definition. This visual, on display throughout the semester, serves as the placeholder to document the class content on the background, issues and trends in the field.

[Place Table 2 about here.] 
We examine each definition by acknowledging that early elements of the field were audio-visual education, instructional psychology, and systematic approaches to education. Key definition discussion points are shown in Table 2.

The remainder of the course focuses on the history, background and trends in five areas, and provides the support for the content and activities implemented. Table 3 includes a summary of each foundation and the activities used to teach the content.

[Place Table 3 about here.]

The audio-visual, communication and technological foundations of the field. The focus on the audio-visual, communication and technological foundation is on the early history and movement, the theoretical bases of audio-visual education, communication, and the resulting paradigm shifts. The readings in Januszewski and Molenda (2008) for this section are in chapters four and eight, with students' assigned additional supplemental articles (See Table 2, Week 3, 4 and 5). Presented with historical newspapers, books and audio-visual materials, the instructional activities include a "look back" at examples of audio and visual education. The students view silent motion pictures, projected slides, listen to an old radio clip and watch an educational film with sound. We look at an example of a textbook, a teaching machine, and programmed instruction and discuss the evolution of visual aids in teaching. Using the posted timeline, we place the evolution of the theory and practice of audio-visuals, communication and technology in their appropriate place and discuss how media triggers paradigm shifts. From watching audio-visual materials, to creating learning environments, to the microcomputer, the Internet, Web-based learning, blended learning and on the cusp of learning through mobile media, the outcome of this experience is to have students trace 
the evolution of the audio-visual and technological theories and products, and demonstrate how they have impacted and continue to shape the field.

The discussion continues as we look at media research and mediated instruction, and its future trends. We analyze the work of James Finn $(1957,1957$ a, 1960) on automation, education and promotion of the concept of instructional technology, and follow the professional evolution of DAVI to AECT and discuss the role theory and technology played in the development of the organization. Finally, we visit the ClarkKozma debate $(1983,1994)$ on the influence of media on learning. Students reproduce the debate by reframing and performing the debate for today. Our discussion on audiovisual, communication and technological foundations of the field concludes, and we move into the systems foundations of the field.

Systems foundations of the field. The systems foundation's focus is on the history of systems theory and applications in education and training, and current applications of the systems approach. The readings in Januszewski and Molenda (2008) are on pages 105 - 130, and chapter 3, with students' assigned additional supplemental articles (See Table 1, Week 6 and 7). We begin by revisiting the timeline and looking at the work of Charles Hoban (Ely \& Plomp, 1963) and Leonard Silvern (1968) who created the momentum behind the idea of the systems approach, which eventually became a foundation of the field. Students then review numerous instructional systems design models created in the 1970's during the systems approach explosion. Each of several models is critiqued not for its components, rather for when it was created, who it was created by and for what purpose, and the findings are posted on the timeline. The goal is to have students understand the state of the US during the systems explosion, and the practical application 
of the theory to instructional design. We then examine alternatives to traditional design systems and models. Using the models as guides, I have the students work in pairs to "create their ideal" model, and they must be able to defend each step and support their rationale with literature.

During the final systems foundation class, materials are provided, and students work in teams of three or four creating an educational system including the following components:

- the environment inputs that enter

- the environment and supra-system constraints upon the system

- the product the supra-system creates and how they influence the operation of the supra-system

- $\quad$ one sub-system structure of the system

- other related sub systems

- $\quad$ some of the self-stabilization and self-organizations constructs (feedback) Presentations of their system follow where students discuss the application of system theory in their work. These "systems" represent the culmination of their study on the historical, theoretical, and practical application of the systems foundation. It is now time, for the compass to direct us to the psychological and philosophical foundations of the field.

Psychological and philosophical foundations of the field. In this unit the focus is on the psychological base, and the emphasis on individualized instruction. The main reading in chapter 2 in Januszewski and Molenda (2008) with additional supplemental articles (See Table 1, Week 8 and 9). 
The compass directs us to pre-World War II where primary research focused on using machines and materials in the classroom to post-World War II where research centered on the learning process and the mediation of learning with instructional materials. The students watch film clips of the war and training of soldiers. Working with the timeline, they post information they have researched on schools, hospitals, military training facilities and research projects taking place from the early 1900 s with the expansion of the individualized curriculum movement, to examples of individualized instruction (Keller, 1968). Original examples of "teaching machines" are used to discover the early influences of B. F. Skinner and how the machines (1958) led to programmed and individualized instruction. We discuss the re-orientation from behavioral to cognitive learning theory, motivation theories, and organizational psychology.

Students then work with a current example of interactive computer course materials on the current trends in IT from the psychological and philosophical foundations. The goal is to have students discover the new aspects of individualized instruction concepts including the emphasis on learner control and the constructivist philosophy. Students document the similarities and differences, and then we move to our last foundation, management.

Management foundations of the field. We focus the management foundation of media utilization and resource management. The main readings in Januszewski and Molenda (2008) are chapters 5 and 6 with additional supplemental articles (See Table 1, Week 10 and 11). We reflect on each of the foundations we have already explored, and students brainstorm a list of the uses of management in educational/instructional technology. We look at delivery system management, hardware and software 
requirements, technical support to users and operators, and discuss how management is a function performed by us as professionals in the field. We then discuss the application of management concepts critical to the development and effective use of instructional methods and materials.

In final review of the semester, we revisit the timeline to review the origins of the early 1900's management foundation in education where school administration filtered down into the classroom. We examine Finn's (1960) management view as a conceptual connection between management and technology, and Hoban's (1965) view which stated that technology is a... complex, integrated organization of men and machines, ideas, procedures and management, and maintained that the central problem of education is not learning, but the management of learning. The compass now points us to: is the central problem of education learning or the management of learning? The final management foundation activity has each student take a position, search the literature for one week, and in an interview format, explain their position and rationale for it. The class votes to attempt to come to consensus about this question, and it is now time to move to the final foundation of the course.

The foundations of professional practice. The course ends with a look at the foundations of professional practice. Here we focus on the development of the profession and of the professional. The readings in the Januszewski and Molenda (2008) are chapters 9 and 11, and supplemental articles (See Table 1, Week 14). The students engage in a number of participatory activities including "response cards" (Silberman, 2006) where index cards are used to write their thoughts about the values and ethics emphasized in educational technology, which initiates the reflection and discussion. 
With the technological advances, it is imperative that we as a profession discuss our ethical rights and responsibilities. To do this, I initiate our last activity, a "dialog session" (Senge, 1994), where we do not attempt to answer a question; rather our purpose is to explore the complex issue of professional ethics. My goal is to have the students realize that the world of educational technology is one in constant flux, and as the profession evolves so must we as professionals.

Before the conclusion of our last class, we revisit the posted timeline. I ask students a series of questions including: "When do you think the greatest strides in theory, practice and professional development have taken place? What place on the timeline would you like to have been as a practitioner and as a theorist? Where do you think we are going next and how do you see us getting there? What lessons have we learned from the past?" I reinforce that we cannot know where we are going unless we look at where we have been.

\section{References}

Association for Educational Communications and Technology. (1972). The field of educational technology: a statement of definition. Audio-Visual Instruction, 17(8), 36-43.

Association for Educational Communications and Technology. (1977). The definition of educational technology. Washington, D.C.: AECT.

Clark, R. E. (1983). Reconsidering research on learning from media. Review of Educational Research, 53, 445-460. 
Commission on Instructional Technology. (1970). To improve learning: A report to the President and the Congress of the Unites States. Washington, D.C.: U.S. Government Printing Office.

Ely, D.P. (1963). The changing role of the audiovisual process: A definition and glossary of related terms. Audiovisual Communication Review, 11(1), Supplement 6.

Finn, J.D. (1957). Automation and education: I. General aspects. AV Communication Review, 5(1), 343-360.

Finn, J.D. (1957a). Automation and education: II. Automatizing the classroomBackground of the effort. AV Communication Review, 5(2), 451-467.

Finn, J.D. (1960). Automation and education: III. Technology and the instructional process. AV Communication Review, 8(1), 5-26.

Hoban, C.F. (1965). From theory to policy decisions. Educational Technology Research and Development, 13(2), 121-139.

Hoban, C.F. Jr. (1977). A systems approach to audiovisual communications. In D.P.Ely \& T. Plomp (Eds.) Classic writings on instructional technology. pp. $57-64$. Englewood, Libraries Unlimited.

Januszewski, A. \& Molenda, M. (2008) Educational technology: A definition with commentary. New York, NY: Lawrence Erlbaum, Inc.

Keller, F.S. (1968). “Good-bye, teacher...”. In D.P.Ely \& T. Plomp (Eds.) Classic writings on instructional technology. pp. 183 - 197. Englewood, CO: Libraries Unlimited.

Kozma, R.B. (1994). Will media influence learning? Reframing the debate. Educational Technology Research \& Development,42(2), 7-19. 
Seels, B. \& Richey, R. (1994) Instructional technology: The definition and domains of the field. Washington DC: Association for Educational Communications and Technology.

Senge, P. (1994) The fifth discipline fieldbook. New York: Doubleday.

Silberman, M. (2004) Active training: A handbook of techniques, designs, case examples, and tips. San Francisco: John Wiley \& Sons, Inc.

Silvern, L.C. (1968). Systems engineering of education I: Evolution of systems thinking in education (selected pages). Los Angeles: Education and Training Consultants Co.

Skinner, B.F. (1958). Teaching Machines. In D.P.Ely \& T. Plomp (Eds.) Classic writings on instructional technology. pp. 211 -227. Englewood, Libraries Unlimited.

\section{Author Biography}

Monica W. Tracey is an associate professor in instructional technology at Wayne State University, Detroit, Michigan. Her research and teaching focuses on instructional design theory and practice, designer model use and instructional design model validation. 